\title{
ПРОБЛЕМИ І НАПРЯМИ ПІДВИЩЕННЯ ЕФЕКТИВНОСТІ ДІЯЛЬНОСТІ ПІДПРИЕМСТВ ДЕРЖАВНОГО СЕКТОРУ ЕКОНОМІКИ УКРАЇНИ
}

\section{ПРОБЛЕМЫ И НАПРАВЛЕНИЯ ПОВЫШЕНИЯ ЭФФЕКТИВНОСТИ ДЕЯТЕЛЬНОСТИ ПРЕДПРИЯТИЙ ГОСУДАРСТВЕННОГО СЕКТОРА ЭКОНОМИКИ УКРАИНЫ}

\section{PROBLEMS AND DIRECTIONS OF IMPROVING OF THE STATE SECTOR ENTERPRISES IN ECONOMY OF UKRAINE EFFICIENCY}

В статті розглянуті проблеми управління підприємствами державного сектору економіки України. Узагальнено та класифіковано засади внутрішньої економічної політики краӥни як ключової основи діяльності підприємств. Виявлено принципові протиріччя між положеннями законодавчої бази, нормативними регламентами та методологічними підходами до управління державним сектором економіки; розкрито їх невідповідність засадам внутрішньої економічної політики. Проаналізовано економікоправове середовище функиіонування підприємств державного сектору. Досліджено невідповідність сформованої практики призначення керівників державних та муніципальних підприємств чинній нормативній базі. Проведено порівняльний аналіз систем оплати праці керівників таких підприємств в Україні та Росії, виявлено недосконалість та суперечливість вітчизняної системи. На иих засадах сформульовано висновок про необхідність реформування та приведення у відповідність системи управління підприємствами державного сектору, запропоновано першочергові заходи удосконалення управління.

Ключові слова: підприємство, державний сектор економіки, внутрішня економічна політика, управління.

В статье рассмотрень отдельные проблемь управления предприятиями государственного сектора экономики Украины. Обобщены и классифицированы принципь внутренней экономической политики страны как основы деятельности предприятий. Выявлень принципиальные противоречия между положениями законодательной базы, нормативными регламентами $и$ методологическими подходами $\kappa$ управлению государственным сектором экономики; раскрыто их несоответствие принципам внутренней экономической политики. Проанализирована экономико-правовая среда функиионирования государственных предприятий. Исследовано несоответствие сложившейся практики назначения руководителей таких предприятий действующей нормативной базе. Проведен сравнительный анализ систем оплаты труда руководителей предприятий в Украине и России, выявлена противоречивость отечественной системь. На этой основе сформулирован вывод о необходимости реформирования и приведения в соответствие системы управления предприятиями государственного сектора и предложены первоочередные мероприятия. 
Ключевые слова: предприятие, государственный сектор экономики, внутренняя экономическая политика, управление.

Some of the problems of managing enterprises of state sector in Ukraine are revealed in the article. The principles of domestic economic policy as a main basis for businesses are summarized and classified. The fundamental contradictions between provisions of the legal framework, normative regulations and methodological approaches to the management of state sector of economy are detected as well as disclosed their discrepancy to principles of internal economic policy. Economic and legal environment of state sector functioning are analyzed. The maladjustment of existing practice of managers of state and municipal enterprises appointment with current normative base are studied. A comparative analysis of managers salary system in Ukraine and Russia are performed, imperfections and inconsistency of domestic salary system are revealed. On this basis opinion on the necessity of reforming and bringing in conformity of state enterprises management system are formulated.

Keywords: enterprise, public sector of economy, internal economic policy management.

Вступ. Державний сектор економіки представлений в усіх країнах світу. Його доцільність, а також суттєвий вплив на економіку країни $\epsilon$ безсумнівним. Створення системи управління державним сектором економіки $\epsilon$ одним із основних завдань державної політики України $[1,2]$. Проблеми підвищення ефективності діяльності державних підприємств набувають стратегічного значення.

Питанням розвитку державного сектора економіки у сучасних умовах господарювання присвячені праці В. Варнавського, А. Гальчинського, А. Мельника, О. Пасхавера, М. Чумаченка. Проблеми ефективності діяльності підприємств державного сектора висвітлені в працях Є.Балацкого, А. Джумова, . Жадана, М. Камишанської, В. Конишева, Л. Кузьменко, Л. Червової, М. Чечетова, В. Цветкова та інших.

Однак ефективність діяльності вітчизняних державних підприємств залишається надзвичайно низькою, їх можливості не використовуються повною мірою, через що не вдається досягнути динамічного розвитку. Це пояснюється не лише тим, що в процесі формування ринкової економіки найбільш привабливі об'єкти державної власності виявилися приватизованими, що привело до підриву матеріальної основи державного сектору, але й значними пробілами в теоретико-методологічних та практичних дослідженнях в цьому напрямку. Крім того, існують значні протиріччя між положеннями законодавчої бази, нормативними регламентами та методологічними підходами до управління державним сектором економіки. Це дає грунт для наукових досліджень у напрямку пошуку можливостей підвищення ефективності діяльності державних підприємств.

Постановка завдання. Стаття присвячена виявленню та аналізу проблем, що стримують розвиток підприємств державного сектору економіки України та обгрунтуванню напрямків підвищення ефективності їх діяльності. 
Методологія. Дослідження проводилося на основі загальнонаукової методології, що передбачає системний підхід до вирішення проблем. Застосовувалися загальнонаукові методи: наукової абстракції, аналізу та синтезу, індукції та дедукції, якісного та кількісного аналізу. Теоретичною базою $є$ концепції, положення й висновки, що містяться в наукових працях вітчизняних i закордонних економістів. Інформаційну базу дослідження склали літературні джерела за даною темою, документи й матеріали органів державної влади. Емпіричною основою $\epsilon$ дані статистичних збірників, публікації періодичних видань.

Результати дослідження. Державний сектор становить значну частку національної економіки України (37 відсотків валового внутрішнього продукту) та відіграє важливу роль в іiі реальному секторі. Однак, за результатами оцінки Міністерства економічного розвитку України, 60 відсотків державних підприємств $є$ неефективними [2]. Для виявлення проблем, що стримують розвиток підприємств державного сектору, доцільно виділити систему чинників, які визначають статичну і динамічну ефективність діяльності підприємств.

За загальним визначенням, підприємство, не залежно від форми власності, є суб'єктом господарювання, що здійснює підприємницьку діяльність. Підприємництво представляє собою самостійну, ініціативну, системну, на власний ризик господарську діяльність, що здійснюється з метою досягнення економічних і соціальних результатів та одержання прибутку [4, ст. 42]. Система чинників, які визначають статичну і динамічну ефективність функціонування підприємств, складається із наступних конструктивних блоків:

1. Зовнішнє господарське (економіко-правового) середовища, у якому знаходяться підприємства.

2. Принципи і стратегії функціонування і розвитку підприємств.

3. Система управління підприємством, яка містить в собі підсистеми ідентифікації господарського середовища, формалізації мети, імплементації іiі у виробничих та економічних планах і завданнях структурних підрозділів, ресурсного забезпечення, персоналізації завдань, контролю, оцінки діяльності.

4. Система економічної і морального мотивації (стимулювання) персоналу у дотриманні належної виробничої поведінки відповідно до чинних регламентів та загальної мети підприємства.

5. Корпоративна доктрина (регламентний кодекс) поведінки працівників.

6. Організаційна структура підприємництва.

7. Організаційно-правова форма та конструкція підприємства. 
Підприємства досягають максимальної ефективності лише у разі повної взаємної відповідності всіх зазначених складових. Їх більша чи менша взаємна невідповідність знижує можливості розвитку підприємства.

Держава, державні органи та органи місцевого самоврядування не $\epsilon$ суб' єктами господарювання [4, ст. 8-1], оскільки вони не є персоніфікованими носіями iї виробничих, технологічних, соціальних та економічних інтересів, які $€$ рушійною силою підприємництва. У зв'язку з цим всі чинники державного підприємництва повинні забезпечувати повну ідентифікацію інтересів всіх персоніфікацій, які від імені держави здійснюють ті чи інші повноваження і управлінські функції, з інтересами держави.

В іншому випадку виникатиме «конфлікт інтересів», державні підприємства будуть в тій чи іншій мірі відірваними від інтересів держави і діяти всупереч їм. Така ситуація $є$ притаманною практично для всіх країн, де інституційна структура державного сектору не розбудована належним чином, а самі інституції організовані несистемно.

Проаналізуємо більш детально характер впливу окремих чинників ефективності діяльності на державні підприємства.

Згідно чинного законодавства України, управління державним сектором економіки має здійснюватися відповідно до засад внутрішньої та зовнішньої політики в цілому та засад внутрішньої політики в економічній сфері зокрема [4, ст. 21-1]. Засади внутрішньої політики в економічній сфері можуть бути узагальнені, як представлено в таблиці.

Таблиця 1

Узагальнення засади внутрішньої політики України в економічній сфері

\begin{tabular}{|c|c|}
\hline $\begin{array}{l}\text { Складова } \\
\text { політики }\end{array}$ & $\begin{array}{l}\text { Напрями } \\
\text { політики }\end{array}$ \\
\hline 1. Антициклічна & $\begin{array}{l}\text { 1.1. Забезпечення конкурентоспроможності національної економіки, } \\
\text { високих темпів її зростання, макроекономічної стабільності. } \\
\text { 1.2. Гарантування державою непорушності усіх форм власності. } \\
\text { 1.3. Впровадження європейських підходів у сфері делегування функцій } \\
\text { держави суб'єктам господарювання. } \\
\text { 1.4. Забезпечення ефективного управління об'єктами державної власності, } \\
\text { запровадження прозорого та ефективного механізму реалізації державою } \\
\text { своїх прав власника }\end{array}$ \\
\hline 2. Структурна & $\begin{array}{l}\text { 2.1. Досягнення високого рівня енергетичної безпеки, диверсифікація } \\
\text { джерел постачання енергоносї̈в, збільшення обсягу їх видобутку. } \\
\text { 2.2. Формування інфраструктури ринку земель. } \\
\text { 2.3. Розбудова транспортної інфраструктури, інтеграція транспортних } \\
\text { мереж України у міжнародні транспортні коридори. } \\
\text { 2.4. Переведення українських газо-, нафтотранспортних і електричних } \\
\text { мереж на умови функціонування, що діють у державах ЄС. } \\
\text { 2.5. Ефективне використання земель сільськогосподарського } \\
\text { призначення, формування конкурентоспроможного АПК. }\end{array}$ \\
\hline
\end{tabular}




\begin{tabular}{|c|c|}
\hline $\begin{array}{l}\text { Складова } \\
\text { політики }\end{array}$ & $\begin{array}{l}\text { Напрями } \\
\text { політики }\end{array}$ \\
\hline $\begin{array}{l}\text { 3. Інноваційно- } \\
\text { інвестиційна }\end{array}$ & $\begin{array}{l}\text { 3.1. Інтенсифікація інвестиційної та інноваційної діяльності, створення } \\
\text { системи страхування інвестиційних ризиків, стимулювання спрямування } \\
\text { заощаджень громадян на інвестування економіки. } \\
\text { 3.2. Економічне стимулювання для заохочення модернізації виробництва, } \\
\text { спрямування інвестицій у новітні технології, формування інноваційної } \\
\text { інфраструктури та державних програм промислової модернізації. } \\
\text { 3.3. Перехід від фіскальної до інвестиційно-орієнтованої моделі } \\
\text { приватизації. } \\
\text { 3.4. Розвиток механізмів державно-приватного партнерства для залучення } \\
\text { інвестицій у модернізацію промислової інфраструктури. } \\
\text { 3.5. Провадження ринкових інструментів акумулювання і перерозподілу } \\
\text { довгострокових фінансових ресурсів. }\end{array}$ \\
\hline $\begin{array}{l}\text { 4. Науково- } \\
\text { технічна }\end{array}$ & $\begin{array}{l}\text { 4.1. Підвищення ролі вищої освіти і науки як основ «економіки знань». } \\
\text { 4.2. Реформування, розвиток системи вищої освіти і науки, забезпечення їх } \\
\text { інтеграції в світовий освітній і науковий простір, запровадження принципів та } \\
\text { стандартів Болонського процесу у ВНЗ. } \\
\text { 4.3. Забезпечення ефективного захисту права інтелектуальної власності, в } \\
\text { тому числі авторських і суміжних прав. }\end{array}$ \\
\hline 5. Конкурентна & $\begin{array}{l}\text { 5.1. Розвиток конкуренції, забезпечення регулювання діяльності } \\
\text { природних монополій, недопущення проявів монополізму. } \\
\text { 5.2. Детінізація економіки, створення сприятливих умов для діяльності } \\
\text { економічних агентів у легальному правовому полі. } \\
\text { 5.3. Зниження тиску на бізнес з боку контролюючих органів. } \\
\text { 5.4. Розвиток внутрішнього ринку, підвищення його ефективності та } \\
\text { вдосконалення механізмів державного регулювання, забезпечення } \\
\text { збалансованості попиту та пропозиції на окремих ринках. } \\
\text { 5.5. Перехід на європейську модель ринкового нагляду, якості та безпеки } \\
\text { продукції. } \\
\text { 5.6. Впровадження енерго- та ресурсозберігаючих технологій виробництва. }\end{array}$ \\
\hline $\begin{array}{l}\text { 6. Грошово- } \\
\text { кредитна } \\
\text { (монетарна) }\end{array}$ & $\begin{array}{l}\text { 6.1. Проведення ефективної політики управління державним боргом. } \\
\text { 6.2. Розвиток, зміцнення банківської системи та небанківських фінустанов. } \\
\text { 6.3. Підвищення рівня захисту прав вкладників. } \\
\text { 6.4. Забезпечення інституційної і фінансової незалежності НБУ. } \\
\text { 6.5. Підвищення результативності державних видатків. } \\
\text { 6.6. Розвиток ліквідного та надійного фондового ринку, ефективне } \\
\text { функціонування системи депозитарного обліку цінних паперів. }\end{array}$ \\
\hline $\begin{array}{l}\text { 7. Бюджетно- } \\
\text { податкова } \\
\text { (фіскальна) }\end{array}$ & $\begin{array}{l}\text { 7.1. Проведення раціональної податкової політики, зниження } \\
\text { податкового навантаження на економіку, розширення бази оподаткування. } \\
\text { 7.2. Проведення прозорої, виваженої бюджетної політики. } \\
\text { 7.3. Перенесення податкового навантаження з мобільних факторів } \\
\text { виробництва (праці та капіталу) на споживання, насамперед шкідливої } \\
\text { для здоров'я людей продукції, ресурсні та екологічні платежі. }\end{array}$ \\
\hline 8. Цінова & $\begin{array}{l}\text { 8.1. Забезпечення низького рівня інфляції. } \\
\text { 8.2. Проведення узгодженої антиінфляційної політики та забезпечення } \\
\text { цінової і валютно-курсової стабільності. }\end{array}$ \\
\hline 9. Соціальна & 9.1. Ведення обов'язкового накопичувального пенсійного забезпечення. \\
\hline
\end{tabular}




\begin{tabular}{|l|l|}
\hline \multicolumn{1}{|c|}{$\begin{array}{c}\text { Складова } \\
\text { політики }\end{array}$} & \multicolumn{1}{c|}{$\begin{array}{c}\text { Напрями } \\
\text { політики }\end{array}$} \\
\hline & $\begin{array}{l}\text { 9.2. Створення сприятливих умов підприємництва, спрощення умов } \\
\text { започаткування бізнесу та виходу з нього, спрощення системи дозволів. }\end{array}$ \\
\hline 10. Регіональна & $\begin{array}{l}\text { 10.1. Забезпечення економічної збалансованості розвитку регіонів, } \\
\text { узгдженості напрямів їх розвитку із загальнонаціональними потребами. }\end{array}$ \\
\hline $\begin{array}{l}\text { 11. Природо- } \\
\text { охоронна } \\
\text { (екологічна) }\end{array}$ & $\begin{array}{l}\text { 11.1. Збереження навколишнього середовища, вдосконалення національної } \\
\text { екологічної політики, стимулювання розвитку екобезпечних технологій. }\end{array}$ \\
$\begin{array}{l}\text { 11.2. Підвищення рівня захисту населення і територій від надзвичайних } \\
\text { ситуацій техногенного та природного характеру. } \\
\text { 11.3. Впровадження системи збалансованого використання ресурсів. }\end{array}$ \\
\hline
\end{tabular}

Джерело: складено автором на основі [1]

На сьогоднішній день законодавча база, нормативні регламенти i методологічні підходи до управління державним сектором економіки i підприємства не відповідають засадничим принципам державної політики. Зокрема, таким як «впровадження європейських підходів у сфері делегування функцій держави суб'єктам господарювання» (табл., $n .1 .3)$ або «забезпечення ефективного управління об'єктами державної власності, запровадження прозорого та ефективного механізму реалізації державою своїх прав власника» (табл., n. 1.4).

Окремі положення засад економічної політики держави суперечать одне одному. Наприклад, законом передбачено «розвиток конкуренції» (табл., n. 5.1) та лише «зниження тиску на бізнес з боку контролюючих органів» (табл., n. 5.3). Крім того, засадами економічної політики взагалі не передбачено суттєвого скорочення частки державного i комунального секторів економіки.

Для керівництва господарською діяльністю підприємства власники або уповноважений ними орган призначає чи обирає керівника підприємства. Деперсоніфікований характер державної та муніципальної власності значно ускладнює можливості ідентифікації інтересів власників, підприємств і найманих працівників i, таким чином, можливості ефективного використання економічного та виробничого потенціалу підприємств цих форм власності.

Також слід зазначити, що в основному державні та муніципальні підприємства охоплюють такі види діяльності, для яких зазначені вище економічні чинники не $\epsilon$ вирішальними, або які відносяться до сфери природних чи інших монополій, і на них не поширюється конкуренція.

Як правило, з метою гармонізації інтересів власників, керівників та працівників укладаються трудові угоди, що регулюють їх взаємовідносини. Але практика укладення контрактів найму керівників державних та комунальних підприємств 3 уповноваженими державними органами управління, 3 одного боку, та колективних договорів між трудовими колективами і керівниками самих підприємств, 3 іншого боку, фактично не 
забезпечує гармонізації інтересів персоніфікованих учасників підприємництва з інтересами неперсоніфікованої «абстрактної» держави або ії уповноважених органів ні на стадії їх укладення, ні на стадії контролю за їх виконанням, і носить, переважно, формальний характер.

Практика призначення керівників таких підприємств не відповідає або лише формально відповідає чинній нормативній базі, якою передбачено відбору кандидатур на конкурсних засадах [5]. Зокрема, введення процедури погодження кандидатур керівників таких підприємств з головами місцевих державних адміністрацій [6] практично суперечить сутності конкурсного відбору та нейтралізує його результати.

Більш того, наявність профільної освітньої підготовки та практичного досвіду керівництва підприємствами в ринкових умовах формально не $є$ обов'язковою передумовою для участі у конкурсах і фактичного призначення на посади керівників державних підприємств. Члени виконавчих та контролюючих органів управління державними підприємствами призначаються або обираються без проходження будь-якої формалізованої та незалежної процедури тестування відповідності їх кваліфікації і досвіду посадовим вимогам.

Такі поширені у світі інструменти узгодження інтересів менеджменту 3 інтересами підприємств і їх власників, як участь у прибутках та капіталі, в Україні практично не застосовуються, за винятком окремих галузей. Та навіть в цих галузях участь керівників у прибутках підприємств обмежується 10 мінімальними заробітними платами.

Хоча, наприклад, в Росії, де стартові умови в період переходу до ринкових умов господарювання були практично рівними з українськими, навіть керівники компаній третього ешелону за обсягами продаж отримують посадові оклади у розмірі 300-400 тисяч доларів на рік, а також преміальні виплати (бонуси) в розмірі від одного до двох річних окладів в залежності від досягнутого рівня виконання цільових завдань поточного року.

Посадові оклади керівників найбільших російських підприємств становлять близько 1 млн. дол. на рік, а річні бонуси - в розмірах від одного до півтора посадових окладів. В середньому ж виконавчі керівники державних корпорацій в Росії мають посадові оклади у розмірі 500-600 тис. рублів на місяць (18-20 тис. доларів), тобто близько 216-240 тис. доларів на рік. Приблизно стільки ж, скільки в середньому (219 тис. доларів) отримують контролюючі менеджери західноєвропейських компаній. Щоправда, останнім часом заробітна плата в основному $є$ залежною від кінцевих результатів роботи підрозділів та підприємств. Причому, якщо у попередні роки співвідношення зарплати до бонусів в державних компаніях Росії складало відповідно 80/20 або 60/40, то останніми роками спостерігається збільшення частки бонусів (50/50 або навіть 40/60) [7]. 
На відміну від зазначених прикладів, в Україні формою типового контракту з керівниками підприємств, що є у державній власності, взагалі не передбачена залежність рівня заробітної плати чи преміальних виплат керівникам від розмірів активів, прибутків чи рентабельності підприємств, якими вони керують [8]. Навіть не зважаючи на те, що відповідна норма передбачена законом України «Про управління об'єктами права державної власності», де сказано, що «керівникам державних підприємств може виплачуватися винагорода за результатами фінансово-господарської діяльності цих підприємств за рахунок їх чистого прибутку» [9, ст. 14].

Публічний контроль за діяльністю підприємств, в тому числі за допомогою біржових котирувань цінних паперів, емітованих ними, який $є$ найбільш ефективним, в Україні також застосовується несистемно.

Що стосується господарського середовища в країні, воно надзвичайно нестабільне, суперечливо регламентоване та фіскально акцентоване. Ситуація ускладнюється впливом таких чинників як недосконале судочинство i правоохоронна система, збільшення частки тіньової економіки, «незрілість» громадянського суспільства. Зокрема, правоохоронна система працює за алгоритмом презумпції винуватості, а не рідко й прямо пов'язана 3 організованою злочинністю й тіньовою економікою. Частка тіньової економіки, за різними оцінками, коливається в межах від 45 відсотків (за даними Міністерства економічного розвитку і торгівлі України) до 60 відсотків (за оцінкою західних економістів) від офіційного обсягу валового внутрішнього продукту.

Отже повністю обгрунтованим $\epsilon$ те, що за рейтингом Всесвітнього банку «Doing Business», який оцінює умови ведення бізнесу в країнах, Україна в 2013 році посіла лише 112 місце серед 189 країн світу (при тому, що за рік відбулася позитивна динаміка цього показника, викликана, на думку експертів, запровадженням системи електронної звітності). В тому числі за критеріями легкості отримання дозволів на будівництво, підключення до загальнодержавних електричних мереж та прозорості стягнення податків відповідно 68-е, 182-е та 157-е місця. I лише за двома критеріями із десяти умови отримання кредитів та забезпечення їх виконання - Україна посідала місця в межах першої півсотні. Прогнозні оцінки на 2015 рік дещо вищі, але не суттєво [10].

Узагальнюючи, слід зазначити, що стан державного сектору в Україні характеризується такими негативними рисами як: недосконалість структури та організаційно-правових форм господарювання; суперечливістю нормативноправової бази та розпорошеністю і неузгодженістю функцій управління між окремими органами; неефективною системою управління як уповноважених органів, так і менеджменту самих підприємств; відсутністю належної прозорості при прийнятті стратегічних рішень, наявністю проявів корупції та 
рейдерства; i, як наслідок, низькими показниками ефективності діяльності та доходності активів.

Висновки. 3 урахуванням визначених проблематичних умов діяльності, підприємствам державного сектору економіки України надзвичайно важко забезпечити ефективність своєї діяльності. Зміна організаційно-правових форм підприємств, зокрема, їх організаційна консолідація, є важливою, але недостатньою передумовою іiі підвищення. Вона дозволить отримати лише разовий економічний ефект за рахунок економії витрат внаслідок централізації деяких виробництв і функціональних підрозділів або скорочення невиробничої сфери. На мою думку, для цього необхідне системне реформування всієї системи управління державною власністю. Починаючи 3 правових засад і мотивації керівників до покращання результатів діяльності, та закінчуючи кардинальним підвищенням рівня стратегічного планування розвитку підприємств, забезпеченням ефективного публічного контролю за рішеннями уповноважених органів і ефективністю діяльності державних підприємств. I саме консолідація державних активів (концентрація i централізація капіталів) дозволить створити необхідні й достатні передумови для комплексного покращання моделі функціонування й інноваційного розвитку державного підприємництва та більш повного розкриття потенціалу державного сектору економіки.

Науковою новизною дослідження $є$ ідентифікація та висвітлення протиріч між положеннями законодавчої бази, нормативними регламентами та методологічними підходами до управління підприємствами державного сектору економіки України, що є обов'язковою передумовою для формування напрямів підвищення ефективності їх діяльності. Отримані результати потребують подальшого науково-методичного опрацювання та уточнення. Необхідним є приведення у відповідність нормативно-законодавчої бази та розробка адекватної методології управління державним сектором економіки у відповідності до засад внутрішньої економічної політики України.

\section{Література:}

1. Про засади внутрішньої і зовнішньої політики: Закон України від 01.07.2010p. №2411-VI [Електронний ресурс]. - Режим доступу: http://zakon2.rada.gov.ua/laws/show/2411-17.

2. Державна програма активізації розвитку економіки України на 2013-2014 роки [Електронний ресурс]: затверджено Постановою Кабінету Міністрів України від 27.02.2013p. №187 // Сдиний веб-портал органів виконавчої влади України. Режим доступу http://www.kmu.gov.ua/control/publish/ article?art_id=246247059.

3. Рудченко О. Управління державним сектором: проблеми та перспективи [Електронний ресурс] / О. Рудченко, М. Шкільняк // Соціально-економічні проблеми i держава. - 2011. - Вип. 2 (5). — Режим доступу: http://sepd.tntu.edu.ua/images/stories/pdf/2011/11royptp.pdf. 
4. Господарський кодекс України. Прийнятий Верховною Радою України 16.01.2003p. №436-IV [Електронний ресурс]. - Режим доступу: http://zakon4.rada.gov.ua/laws/show/436-15.

5. Про проведення конкурсного відбору керівників державних суб'єктів господарювання: Постанова Кабінету Міністрів України від 03.09.2008p. №777 [Електронний ресурс]. — Режим доступу: http://zakon1.rada.gov.ua/laws/show/2342005-\%D0\%BF.

6. Про деякі питання забезпечення здійснення повноважень місцевими державними адміністраціями: Указ Президента України від 16.04.2010p. № 542/2010 [Електронний ресурс]. - Режим доступу: http://www.president.gov.ua/documents/ 11077.html.

7. Экономика падает, а бонусы топ-менеджерам растут. Реалии современной России и СНГ [Электронный ресурс] // Новости политических партий России и СНГ. — Режим доступа: http://www.qwas.ru/russia/kprf.

8. Про типову форму контракту з керівником підприємства, що є у державній власності: Постанова Кабінету Міністрів України від 02.08.1995р. №597 [Електронний ресурс]. — Режим доступу: http://zakon3.rada.gov.ua/laws/show/597-95-\%D0\%BF.

9. Про управління об'єктами державної власност: Закон України від 21.09.2006p. №185-V [Електронний pecypc]. - Режим доступу: http://zakon4.rada.gov.ua/laws/show/185-16.

10. Doing business — 2014. Measuring Business Regulation / The World Bank Group [Electronic resource]. - Mode of access: http://www.doingbusiness.org/ data/exploreeconomies/ukraine. 